\title{
Cooperation or Suffocation
}

\author{
Dr. Colwell is president, University of \\ Chicago.
}

W

HEN I TRIED to think of a rhetorical skeleton on which to arrange my remarks, the first idea or theme that popped into my head was that libraries are like cemeteries. This is not an original discovery of my own, nor is it news to many of you. But when I thought of it and thought of the fact that you are all intimately associated with the operation, maintenance, support and service of libraries, that hardly seemed to me to be a gracious, attractive or conciliatory note on which to begin my remarks. I therefore abandoned it and decided instead that I would say that libraries are the most inefficient and wasteful part of an inefficient and wasteful system of education. But that this is not, in most cases, the fault of the librarian. It is true of libraries that they are like cemeteries in that they never stop growing.

My first public address was in the village of Meshoppen, $\mathrm{Pa}$. It had a population of 927. On the Memorial Day in the spring I was invited as the acting pastor of the Methodist Church, at the ripe old age of $\mathbf{I}$, to give a patriotic address. This address was delivered in the cemetery. And for the first time I realized the obvious fact that cemeteries' population outnumbers any other population. It will not be long, if we continue our present trends in library development, before the population of libraries will outnumber all other populations

${ }^{1}$ Address to the general session of A.C.R.L., Jan. 22, 1949, Chicago. in educational or charitable or public service institutions.

\section{Size in Libraries}

As a matter of fact, size in librariesand I am talking particularly about college and university libraries-has often been pursued for its own sake. There are no prouder words for the university administrator or the librarian to utter than, "Our library is the largest in the South, or in the North, or the West, or the East, or in the state," or in whatever region we happen to be located. Prudence in the matter of building libraries has not consisted in determining the optimum size of a particular library, but in planning the original building so that it can be expanded in at least six directions.

As a matter of fact, this growth in size in college and university libraries has very little reference to the function the library is supposed to perform. Many of us have learned in the last generation that some books are great books. We need to learn also that some books are dead books. Thus libraries resemble cemeteries in the fact that much of what they contain is good for nothing except to enrich the soil. If fifty per cent of what college and university libraries contain was spread on the fields, it would enrich education as well as the soil.

The college library grows through all sorts of strange procedures. It grows through the purchase of duplicates for instructional purposes, and these duplicates are often retained after the instructional 
purpose has been served. It grows through the bequests of alumni or retired members of the faculty whose devotion to the institution surpasses their bibliographical skill. Most of our libraries are loaded down, for example, with volumes of sermons which are included because the author belonged to the church which founded the institution. Or if our ancestry is civil instead of ecclesiastical, our shelves are stuffed with political orations made by the servants of our own states, to say nothing of the collection of "reports."

Again our libraries grow because either the librarian or the college president-or both-believe that the growth of the library enhances their professional reputation. I give you one ludicrous example-and it's the only one I know in which the librarian is the victim. I could tell you 25 on university presidents.

In a theological seminary library, a professor was astonished to discover on the shelves a German periodical whose title as nearly as I can remember it was, Archiv für Pferdeforschung (Journal of Horse Breeding). The librarian had other journals called "Archiv," and she wanted the library to grow.

Much worse is the havoc wrought by presidents, often aided and abetted by foundations, when they pursue special collections for prestige purposes. These collections are enshrined in a fine room, often as seldom entered as the de luxe mausoleum in the cemetery. Sometimes the cause of education is more seriously injured by the use of their contents than by their neglect. The meaningless and mediocre works of a local or regional author are glorified as a special collection, appropriately housed in a magnificent room. Then pressure is put on the professors to publish this "famous" collection. And the quality of scholarly publication is faced with a dilution which it can ill afford.
But much worse than the librarians, worse even than presidents, is the faculty in its influence on the growth of the library. In most institutions today the professor considers the development of the library solely in terms of his individual needs. Neither he nor his colleagues plan the future of the library in terms of the institution's needs. At the best he will see that the library is equipped for study in his own field; at the worst he orders enormous sets of duplicates which are in effect library textbooks and which as such may have some instructional justification, then changes the orders each year-unless he himself has written a textbook in that particular field. He clamors for the library to build up a collection to suit his personal needs and then carries it off a book at a time to his own office. He favors decentralized libraries, while the sciences and the various fields of scholarship today become more and more intimately interrelated. I sympathize with the professor's motives, but I cannot describe his habits as cooperative.

But much more dangerous to the cause of library planning is the professor's library creed. He believes that the future will reveal needs which we cannot now know. $\mathrm{He}$ concludes from this belief that we must order everything and keep everything since someone some day may need it. He is right in his belief that the future will hold needs which we do not now envisage, but he is wrong in his conclusions. The library's future is obscure because all the future is obscure. To deny that we can plan for the library is to deny that we can plan. We were given reason so that we might make reasonable predictions for the future - not to live like academic squirrels.

I know of no set of academic dogmas that are more dangerous to the progress of institutions of higher learning than this negative faith of the professor with regard 
to planning the future of the library. It is time for it to be destroyed, and I believe that it can now finally be exploded. The professor will not take this attitude in regard to the development of his own department. He will not take this attitude in regard to the development of the curriculum. He does not say that we should keep the courses we taught ro years ago because Io years in the future we may need to have a course which we taught ro years ago.

In no other area does he operate on the basis of this negative conviction. I believe that if librarians are insistent enough they can in this generation finally destroy this repudiation of human reason in what is supposed to be one of its citadels.

One of my friends recently told me with considerable pride that his library would soon have more volumes than any other university library in his region. He said, "We will no longer have to say 'we are next to the biggest library,' we will be the biggest." They are now building at his institution an addition to the library and I was confidently assured that they would need another addition in Io more years. Back of this lies institutional competition, institutional pride and institutional jealousy. No one of them a laudable or praiseworthy attitude. It is based partly also on the fact that since trustees of educational institutions are inclined to believe that to be bigger is to be better, the president emphasizes the growth of the library in his annual report, even if he has real achievements to point to, and even though it would have grown if he had not been there.

\section{University Libraries of the Future}

The elimination of institutional competition in this area is in my judgment essential to the improvement of college and university libraries. The dream university of the future will possess or participate in four libraries. Of course this is $m y$ dream library-I am frank to confess you might have one with six. I am willing to settle for four.

The first would be a college or general education library, housed in a building designed for that purpose, and containing, I would say, not more than 50,000 volumes. I assume that the college has from Iooo to 5000 students. But if it has 20,000 it will not need four times 50,000 volumes. The volume needs of the general college library are relatively small and the way that colleges point with pride to tremendous numbers of volumes in their book collections fails to recognize the facts of life.

The second library in a university would be a research library, housed in a building designed for the purpose, one in which the individual graduate student or professor is emancipated into the stacks, but controlled scrupulously at the exit. Such a library can have a fixed number of volumes forever. It should be the current research library. It should have in it the volumes that are essential to the pursuit of research in the decade in which it is operating. It should not try to contain the reserves for the future, nor to perpetuate the catastrophes of the past. Since no one knows exactly how to establish the size of a fixed ceiling research library, I tentatively suggest $1,000,000$ volumes because that is large enough to sound big and impressive, but not too large, I think, to be housed in a building that will not dwarf the other monuments on the campus. As a matter of fact, I realize that those institutions that establish on their own campuses a current research library, with the idea that it will have a fixed ceiling, will almost without exception set the number of volumes in terms of the number they now have, plus some small factor of one kind or another. I recognize this, but $I$ am not reconciled to it. It is an irrational way in which to 
set the limits of this library. But the main thing is to set the limit-to build a research library which in terms of the size of its book holdings can be perpetual.

This will end forever this rat race of constantly building additional wings and maintaining everything as if every book in the library were going to be called for tomorrow and had to be delivered to a professor within Io minutes. I recognize, of course, that the professor wants the book the second he thinks of it. But does that establish any right or obligation upon the library to deliver it to him with that speed? Older civilizations as cultured as ours have survived the delay of half a day in the delivery of a book to the learned world.

This second library, the research library, the active research library of the university would house the books that are needed at a specific time. It would be a very active library. It would be a library for use. It would not keep the vestigial remains of either the teaching or the research interests of bygone days.

The third library would not necessarily be on the campus. It would be a regional library - a libraries' library. And this library would store; it would help to distribute; it would help to develop the research library resources of the entire region. It would hold for our common use the one copy only for the region. And it would hold also the little-used items that once in twenty-five years are looked at again in vain hope by some embryonic research worker who is misled by an attractive title. It would increase our knowledge of each other's holdings and would try to lead us into planning for the good of our region.

Such a library is envisaged in the embryonic midwest inter-library center. The Carnegie Corporation of New York voted a gift of half a million dollars to this center, and an additional quarter of a million if the latter sum could be matched. ${ }^{2}$
The difficulties in the way of establishing effective cooperation throughout a region, with particular emphasis upon research, are great. But most of the difficulties are in our minds. They are our fears of one another, our distrust of each other, our pride in the dimensions of our own activity, and our general lethargy and timidity when confronted with the responsibility of creating something new. Here in the Midwest we are overcoming these difficulties.

This "we" is not editorial. It realistically reflects the sincere cooperation of midwestern librarians and presidents for their common good.

The fourth library has not yet been planned, but it is inevitable. The first regional library will be followed by others. These regional libraries must be related to national and international programs. Through some national institution, preferably the Library of Congress, the work of the individual regional libraries can be correlated. Moreover, we need some single channel and program for effective relationships with the outside world.

Let us assume that in a particular region individual libraries have parts of some important scholarly serial in duplicate. If turned over to the regional library, these parts might well become a complete set. With the complete set as a bargaining resource, the regional library could secure from abroad more valuable titles for its own region than the individual libraries could secure with their fragmentary sets.

Or, let us assume that the Library of Congress must decide how many duplicate sets of important foreign publications to import. A Library of Congress related to a network of regional libraries could make these decisions rapidly and effectively.

\section{(Continued on page 207)}

2 Since Dr. Colwell's address in January, a matching sum of $\$ 250,000$ has been granted by the Rockefeller Foundation.-Editor. 
interpretation of the selection policy for a research library was given by Dr. Wilmans, director of the Prussian State Library to the head of his acquisition department: "Buy documentary material." 9 The generally accepted definition will include the following groups: bibliographies, sources and all monographs which have more than ephemeral value either because of the new research they contain or because of a new presentation of known facts. The instructional and research needs of the individual institution will control closer selection within the above framework.

The acquisition librarian will first satisfy immediate needs, but then he will go beyond the requirements of the faculty. By paying close attention to new fields of research and new methods of investigation he will try to anticipate the requests of the subject specialist.

The significant position of the acquisition librarian as coordinator of purchases in all subject fields is at the same time the source of his greatest weakness. Although he may be a scholar in his own right in one sub-

'Handbuch der Bibliothekswissenschaften, herausgegeben von Fritz Milkau. Leipzig, 1933. Vol. 11, p. 139 . ject field, he will know next to nothing in some branches of learning and will be an amateur at the very best in other disciplines. His bibliographical experience will permit him to make many fairly reliable guesses, but it is not a full substitute for subject knowledge. Being fully aware of his own shortcomings, he will take advantage of the campus telephone on his desk. His foremost obligation is to convince the faculty of his institution of his eagerness to serve them, his appreciation of their advice and suggestions, his willingness to learn and his sincere interest in the growth of the library. $\mathrm{He}$ will then enjoy the enthusiastic support of his faculty and well exemplify Pierce Butler's resounding phrase: "In this age of specialization the librarian alone of all scholars is in a position to see both scientific and humanistic scholarship in the same perspective. Therefore it might seem that the librarian's chief and peculiar office is to promote in modern society a rational equilibrium and a mutual respect between these two forms of intellectual culture." 10

10 Butler, Pierce. "The Research Worker's Approach to Books, the Humanist," in The Acquisition and Cataloging of Books. Chicago, University of Chicago Press, 1940 , p. 283.

\section{Cooperation or Suffocation}

\section{(Continued from page 199 )}

When these bright days come, the work of the librarian and the administrator will change its nature. The college president and librarian can abandon the effort to outdistance their competitors in size. Instead they will devote their efforts to the improvement of quality and to the main- tenance of a library that is truly contemporary.

When we shall have a network of regional libraries effectively related to a national library and to the libraries of the world, I do not know. But I commend this dream to the librarians. 